\title{
Focus on Brain Angiotensin III and Aminopeptidase A in the Control of Hypertension
}

\author{
John W. Wright, ${ }^{1}$ Shigehiko Mizutani, ${ }^{2}$ and Joseph W. Harding ${ }^{1}$ \\ ${ }^{1}$ Departments of Psychology and Veterinary and Comparative Anatomy, Pharmacology, and Physiology and Programs in \\ Neuroscience and Biotechnology, Washington State University, P.O. Box 644820, Pullman, WA 99164-4820, USA \\ ${ }^{2}$ Department of Medical Science of Proteases, Daiya Building Lady's Clinic, Meieki 3-15-1, Nakamura, Nagoya 450-0002, Japan
}

Correspondence should be addressed to John W. Wright, wrightjw@wsu.edu

Received 1 March 2012; Accepted 26 April 2012

Academic Editor: John R. Dietz

Copyright (C) 2012 John W. Wright et al. This is an open access article distributed under the Creative Commons Attribution License, which permits unrestricted use, distribution, and reproduction in any medium, provided the original work is properly cited.

The classic renin-angiotensin system (RAS) was initially described as a hormone system designed to mediate cardiovascular and body water regulation. The discovery of a brain RAS composed of the necessary functional components (angiotensinogen, peptidases, angiotensins, and specific receptor proteins) independent of the peripheral system significantly expanded the possible physiological and pharmacological functions of this system. This paper first describes the enzymatic pathways resulting in active angiotensin ligands and their interaction with $\mathrm{AT}_{1}, \mathrm{AT}_{2}$, and mas receptor subtypes. Recent evidence points to important contributions by brain angiotensin III (AngIII) and aminopeptidases A (APA) and N (APN) in sustaining hypertension. Next, we discuss current approaches to the treatment of hypertension followed by novel strategies that focus on limiting the binding of AngII and AngIII to the $\mathrm{AT}_{1}$ receptor subtype by influencing the activity of APA and APN. We conclude with thoughts concerning future treatment approaches to controlling hypertension and hypotension.

\section{Introduction}

The first physiological insight into blood pressure (BP) regulation was the isolation of kidney renin by Tigerstedt and Bergman in 1897 [1]. This initial work led to a description of renovascular hypertension in animals and humans by Goldblatt and colleagues. [2]. In 1940, Braun-Menendez and coworkers [3] isolated a vasoconstrictive substance from renal venous blood taken from a Goldblatt hypertensive dog. In this same year, Page and Helmer [4] isolated a "renin activator" after injecting renin into an intact animal. This renin activator was later identified as angiotensinogen. The pressor substance was termed "angiotonin" (also referred to as "hypertension"), and was eventually shown to be an octapeptide [5-7]. It was agreed by Braun-Mendez and Page in 1958 to name this octapeptide "angiotensin." Since that time extensive physiological, biochemical and behavioral studies have established a prominent role for angiotensin in blood pressure and body water/electrolyte balance.
This paper initially describes the presently identified angiotensin ligands of the renin-angiotensin system (RAS) and details the enzymes involved in their formation and degradation. The two prominent angiotensin receptor subtypes that bind these ligands $\left(\mathrm{AT}_{1}\right.$ and $\left.\mathrm{AT}_{2}\right)$ have been characterized, as have the roles of angiotensin II (AngII) and angiotensin III (AngIII) in blood pressure regulation. We next focus on current and novel approaches designed to treat hypertension by manipulating aminopeptidases. We conclude with some thoughts on future directions concerning treatment strategies to control hypertension.

\section{Formation of Angiotensin Ligands}

Angiotensin peptides are derived from the precursor protein angiotensinogen through several enzymatic conversion pathways (Figure 1 [8-10]). The decapeptide angiotensin I (AngI) is formed by renin (EC 3.4.23.15) acting upon the amino terminal of angiotensinogen [11]. AngI serves as a substrate 


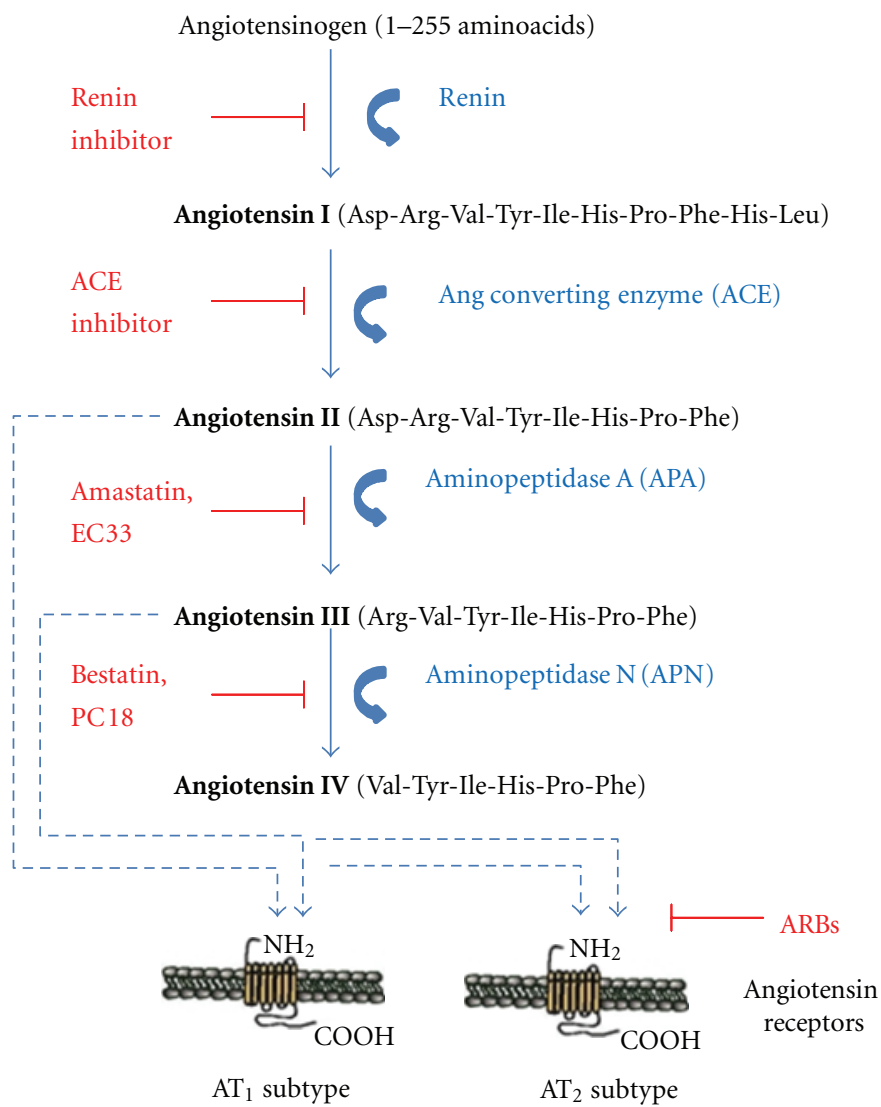

FIGURE 1: The renin-angiotensin pathway including active ligands (bold), enzymes, receptors, and inhibitors involved in central angiotensin mediated blood pressure. Abbreviations: ACE: angiotensin converting enzyme; APA: aminopeptidase A; APN: aminopeptidase N; ARBs: angiotensin receptor blockers.

for angiotensin converting enzyme (ACE: EC 3.4.15.1), a zinc metalloprotease that hydrolyzes the carboxy terminal dipeptide His-Leu to form the octapeptide AngII $[8,12]$. This conversion can also be accomplished by the chymotrypsinlike serine protease, chymase [13]. AngII is converted to the heptapeptide AngIII by glutamyl aminopeptidase A (APA: EC 3.4.11.7, or A-like activity) that cleaves the Asp residue at the N-terminal [14-17]. Membrane alanyl aminopeptidase N (APN: EC 3.4.11.2) cleaves Arg at the N-terminal of AngIII to form the hexapeptide angiotensin IV (AngIV). AngIV can be further converted to Ang(3-7) by carboxypeptidase $\mathrm{P}$ (Carb-P) and propyl oligopeptidase (PO) cleavage of the Pro-Phe bond. Endopeptidases such as chymotrypsin are capable of cleaving the Val, Tyr, and Ile residues, along with dipeptidyl carboxypeptidase that cleaves the His-Pro bond, reducing AngIV and Ang(3-7) to inactive peptide fragments and aminoacid constituents [8, 18-22].

Some years ago the nomenclature committee of the International Union of Biochemistry [23] indicated that APA was likely identical with APN. However, it has been shown that APA cleaves the N-terminal Asp from AngII, but it also cleaves Arg and Val [24]. The speed of Arg and Val cleavage was facilitated when a combination of APA and placental leucine aminopeptidase (P-LAP) was used $[25,26]$.

AngII can also be converted to Ang(1-7) by Carb-P cleavage of Phe [27], by the monopeptidase $\mathrm{ACE}_{2}[28,29]$, or by ACE cleavage of the dipeptide Phe-His from Ang(19) [30]. Ang(1-7) is further converted to $\operatorname{Ang}(2-7)$ by APA acting at the Asp-Arg bond [31]. AngII and AngIII are full agonists at the $\mathrm{AT}_{1}$ and $\mathrm{AT}_{2}$ receptor subtypes (see $[32,33]$ for review). AngIV binds with low affinity at the $\mathrm{AT}_{1}$ and $\mathrm{AT}_{2}$ receptor subtypes, but with high affinity and specificity at the $\mathrm{AT}_{4}$ receptor subtype [34-39]. AngI is biologically inactive; while its metabolites AngII and AngIII mediate pressor and dipsogenic effects via the $\mathrm{AT}_{1}$ and $\mathrm{AT}_{2}$ receptor subtypes [32]. AngIV exerts a much reduced pressor response, also by acting as an agonist at the $\mathrm{AT}_{1}$ receptor subtype [40-44].

A counter regulatory axis to the AngII-AngIII/AT 1 receptor system has recently been proposed consisting of $\mathrm{ACE}_{2}$, and Ang (1-7) acting at the Mas receptor. This system appears to act in opposition by promoting vasodilation, antifibrosis, antihypertrophic and antiproliferative effects (see $[45,46]$ for review) and is further discussed in the next section.

\section{Characterization of the $\mathbf{A T}_{1}, \mathbf{A T _ { 2 }}$, and Mas Receptors}

The $\mathrm{AT}_{1}$ receptor subtype is a $\mathrm{G}$-protein-coupled receptor with signaling via phospholipase- $\mathrm{C}$ and calcium. Thus, the angiotensin ligand binds to the $\mathrm{AT}_{1}$ receptor and induces a conformational change in the receptor protein that activates $\mathrm{G}$ proteins, which in turn, mediate signal transduction. This 
transduction involves several plasma membrane mechanisms including phospholipase- $\mathrm{C},-\mathrm{A}_{2}$, and -D-adenylate cyclase, plus L-type and T-type voltage sensitive calcium channels $[32,47,48]$. The $\mathrm{AT}_{1}$ receptor (now designated $\mathrm{AT}_{1 \mathrm{~A}}$ ) is also coupled to intracellular signaling cascades that regulate gene transcription and the expression of proteins that mediate cellular proliferation and growth in many target tissues. Expression cloning was used to isolate the cDNAs encoding this receptor protein $[49,50]$, and it was found to be a 7-transmembrane domain protein consisting of 359 aminoacids with a mass of approximately $41 \mathrm{kDa}$ [51]. Subsequently, a second $\mathrm{AT}_{1}$ subtype was discovered and designated $\mathrm{AT}_{1 \mathrm{~B}}$ that was also cloned in the rat $[52,53]$, mouse [54], and human [55]. This subtype is approximately 92-95\% homologous with the aminoacid sequence of the $\mathrm{AT}_{1 \mathrm{~A}}$ subtype $[56,57]$. Of these two isoforms, the $\mathrm{AT}_{1 \mathrm{~A}}$ subtype appears to be responsible for the classic functions associated with the brain angiotensin system (see $[58,59]$ for review).

The $\mathrm{AT}_{2}$ receptor subtype has been cloned and sequenced using a rat fetus expression library $[60,61]$, and also evidences a 7-transmembrane domain characteristic of Gprotein-coupled receptors; however, it shows only about 32 $34 \%$ aminoacid sequence identity with the rat $\mathrm{AT}_{1}$ receptor. The $\mathrm{AT}_{2}$ receptor protein includes a 363 aminoacid sequence $(40 \mathrm{kDa})$ with $99 \%$ sequence agreement between rat and mouse and $72 \%$ homology with human [32]. Even though this $\mathrm{AT}_{2}$ receptor possesses structural features in common with members of the 7-transmembrane family of receptors, it displays few if any functional similarities with this group, although it does appear to be G-protein-coupled [32, 60$62]$. While the $\mathrm{AT}_{1}$ receptor subtype is maximally sensitive to AngII, it is also responsive to AngIII. The $\mathrm{AT}_{2}$ receptor subtype appears to be maximally sensitive to AngIII, but AngII also serves as a ligand at this receptor subtype.

The Mas receptor was discovered in 1986 and was initially categorized as a protooncogene because it transformed NIH $3 \mathrm{~T} 3$ cells in a tumorigenicity assay (nude mice) using DNA taken from a human epidermoid carcinoma cell line [63]. Subsequently, it was reported that overexpression of Mas in cones of the retina caused cell death but no tumor formation [64]. Further, transgenic mice overexpressing Mas in the brain failed to reveal tumor formation [65]. Young and colleagues [66] measured a high expression of the Mas receptor in the hippocampus and neocortex of the rat brain. The human Mas cDNA sequence indicated an open reading frame coding for a 325 aminoacid protein [63] belonging to the classification of G-protein coupled receptors. Cellular localization of Mas mRNA has been reported using in situ hybridization with high levels detected in the rat and mouse hippocampus and piriform cortex [67]. This receptor binds Ang(1-7) with high specificity that could not be displaced using AngII or AngIV [68]. While AngII, and to a lesser extent AngIII, have been considered the active peptides derived from angiotensinogen, convincing evidence exists indicating that $\operatorname{Ang}(1-7)$ plays an important role in cardiovascular and pulmonary biology (see $[69,70]$ for review). Ang(1-7), working through the Mas receptor, initiates many biological responses that are opposite to those attributed to AngII. These include vasodilatory, antihypertrophic, antihyperplastic, and antifibrotic action on the heart and vasculature [71-73]. Unlike AngII, Ang(1-7) is generally synthesized from AngII or Ang(1-9), and not AngI [74]. This synthesis is primarily carried out by $\mathrm{ACE}_{2}$ in the heart, vasculature, lungs, and brain $[75,76]$. The potential clinically beneficial effects of augmenting the $\mathrm{ACE}_{2} / \mathrm{Ang}(1-$ 7)/Mas signaling system has spurred the development of $\mathrm{ACE}_{2} / \mathrm{Ang}(1-7) / \mathrm{Mas}$ system potentiating drugs including Mas agonists and $\mathrm{ACE}_{2}$ activators [77].

The functions associated with the activation of each of these receptors are presented in Table 1.

\section{The Pivotal Role of Aminopeptidases in Blood Pressure Regulation}

As indicated above, APA hydrolyzes $\mathrm{N}$-terminal acidic aminoacids. It appears that glutamyl derivatives are more effectively hydrolyzed than aspartyl derivatives, thus this enzyme has also been designated glutamyl aminopeptidase (Glu-AP [22]). Aminopeptidase $\mathrm{N}$ acts on $\mathrm{N}$-terminal neutral aminoacids, and since alanine is most efficiently cleaved by APN, this enzyme is also known as alanyl aminopeptidase (Ala-AP). In addition, it has been referred to as aminopeptidase M (APM) because of its association with pig kidney microsomal membrane fraction from which it was originally purified. Aminopeptidase B (AP-B; EC 3.4.11.6) hydrolyzes basic aminoacids at the $\mathrm{N}$-terminal and is also known as arginine aminopeptidase (Arg-AP). Cystinyl aminopeptidase (Cys-AP; EC 3.4.11.3) hydrolyzes the N-terminal cysteine next to tyrosine of oxytocin and vasopressin. Thus, it is frequently referred to as oxytocinase or vasopressinase. PLAP appears to be equivalent with Cys-AP; while insulinregulated aminopeptidase (IRAP) is the rat homologue of Cys-AP $[78,79]$. Since these enzymes are involved in metabolizing angiotensins, they have often been grouped under the name "angiotensinases."

\section{The Emergence of AngIII and APA as Key Factors in Sustaining Hypertension}

It is now reasonably well established that a major reason for high $\mathrm{BP}$ in the spontaneously hypertensive rat (SHR) model is an overactive brain RAS, and the primary ligand in this regard may be AngIII. Originally, it was reported that intracerebroventricular (i.c.v.) infusion of AngII or AngIII produced dose-dependent elevations in BP with the magnitude of these elevations reasonably equivalent [ 80 , 81]. Higher rates of neuronal firing were shown with the microiontophoresis of AngIII, as compared with AngII, in both the subfornical organ (SFO) [82] and paraventricular nucleus (PVN) [83, 84], two brain structures responsible for mediating BP. Harding et al. [85], using a push-pull cannula into the PVN, showed that $93 \%$ of the releasable angiotensin coeluted with AngIII; while only 7\% eluted with AngII. This suggested that the conversion of AngII to AngIII is rapid and a critical step in maintaining BP. It was next discovered that SHRs were more sensitive to i.c.v.-infused angiotensins than normotensive Wistar-Kyoto (WKY) and Sprague-Dawley 
TABLE 1: Functions associated with ligand activation of the $\mathrm{AT}_{1}$, $\mathrm{AT}_{2}$, and Mas receptors.

\begin{tabular}{l}
\hline $\mathrm{AT}_{1}$ receptor subtype \\
Vasoconstriction \\
Aldosterone release \\
Vasopressin release \\
Cardiac hypertrophy \\
Fibrosis \\
Proliferation \\
Inflammation \\
Platelet aggregation \\
Oxidative stress \\
Endothelial disruption \\
\hline $\mathrm{AT}_{2}$ receptor subtype \\
Vasodilation \\
Antifibrotic \\
Antiproliferative \\
Antihypertrophic \\
Antithrombotic \\
\hline Mas receptor \\
Vasodilation \\
Antifibrotic \\
Antihypertrophic \\
Antithrombotic \\
Promotes endothelial function \\
\hline
\end{tabular}

rats. Further, these angiotensin-induced elevations in $\mathrm{BP}$ remained high for longer durations in the SHR. Pretreatment with the APN inhibitor bestatin potentiated and prolonged the pressor response to both AngII and AngIII. These results suggested that inhibiting the conversion of AngIII to the hexapeptide AngIV prolonged the half-life of AngIII, thus providing a potential mechanism for the higher BP seen in the SHR, that is, a delay in the conversion of AngII to AngIII, and Ang III to AngIV. The extended half-life of brain AngII and AngIII would be expected to prolong heightened activation of the $\mathrm{AT}_{1}$ receptor subtype and thus maintain an elevated BP. Pretreatment with bestatin potentiated and prolonged the pressor response to both AngII and AngIII. We interpreted these results to suggest that inhibiting the conversion of AngIII to the hexapeptide AngIV prolonged the halflife of AngIII, thus providing a plausible explanation for the higher sustained blood pressure seen in the SHR. Next, we demonstrated that the i.c.v. infusion of bestatin elevated BP in both SHR and WKY rats [86]; while the infusion of Ala-AP significantly reduced BP in SHR and WKY rats. Pretreatment with the nonselective angiotensin receptor antagonist, [Sar ${ }^{1}$, $\mathrm{Thr}^{8}$ ] AngII (sarthran, predecessor to Losartan) significantly diminished this Ala-AP-induced drop in BP in SHRs and promoted recovery of BP and heart rate to baseline values in members of both strains. Taken together, these results pointed to an important role for brain AngIII interacting with the $\mathrm{AT}_{1}$ receptor subtype.

We suspected a disruption in brain aminopeptidase activity in the SHR $[87,88]$. To test this hypothesis replacement
Glu-AP was i.c.v.-infused in order to promote the hydrolysis of AngII to AngIII. Results indicated that BP was elevated in both SHR and WKY rats [89]. In contrast, the i.c.v. infusion of Ala-AP, which hydrolyzed AngIII, significantly decreased BP in WKY rats, but especially in SHRs. By the use of metabolically resistant analogues of AngII ([D-Asp $\left.{ }^{1}\right]$ AngII) and AngIII ([D-Arg $\left.{ }^{1}\right]$ AngIII), it was shown that the AngIII analogue generated a much greater pressor response in the SHR than the AngII analogue when i.c.v.-infused [90]. Taken together, these results supported the notion that interfering with the conversion of AngII to AngIII results in a significant reduction in BP [91], and brain AngIII is a much more potent pressor agent than AngII.

\section{Current Treatment Strategies}

In the periphery, the cardiovascular effects due to excessive formation of AngII bear a remarkable resemblance to those observed in response to overactivation of the sympathetic component of the autonomic nervous system and excess norepinephrine. These include ventricular hypertrophy, vasoconstriction, and sodium retention. The synthesis cascade involved in the formation of AngII offers several opportunities for clinical intervention, as does the interaction of AngII and AngIII with the $\mathrm{AT}_{1}$ receptor subtype. These potential points of intervention include treatment with renin inhibitors, ACE inhibitors, APA inhibitors, aldosterone inhibitors, and angiotensin receptor blockers (ARBs).

6.1. Renin Inhibitors. As cardiovascular deficiency progresses, decreased renal perfusion occurs accompanied by increased release of norepinephrine resulting in increased juxtaglomerular renin release into the circulation. Renin is an aspartic proteinase designed to cleave the Leu-Val bond at the amino terminal of angiotensinogen, thus forming the decapeptide AngI. This conversion is considered to be the first rate-limiting step of the RAS. First- and secondgeneration renin inhibitors were peptidomimetics effective at lowering BP in hypertensive patients; however, these inhibitors exhibited very poor oral bioavailability and were subject to high production costs. Third-generation renin inhibitors are nonpeptides, such as Aliskiren, and appear to be more therapeutically promising in that they evidence good duration of action and bioavailability [92].

6.2. ACE Inhibitors. The next potential point of intervention in the angiotensin synthetic cascade is the conversion of AngI to AngII, where ACE inhibitors have utility. ACE hydrolyzes the carboxy terminal dipeptide His-Leu to form AngII [8]. ACE inhibitors have become a primary therapeutic treatment for hypertension and systolic heart failure. The myocardium of patients with failing hearts shows increased levels of ACE mRNA, ACE protein, and ACE activity [93]. The notion that hemodynamic load determines the level of RAS expression in the heart is supported by the observation that ACE increases as the severity of heart failure increases. In agreement, left ventricle ACE and AngII levels change with diastolic ventricular wall stress [94]. A disadvantage of ACE inhibitors concerns their ability to prevent the 
breakdown of bradykinin to inactive peptide fragments. This can result in an accumulation of bradykinin that contributes to angioedema and cough. In some patients, these side effects can be sufficiently troublesome to result in discontinuation of the medication. Even so ACE inhibitors appear to provide long-term positive effects in many patients with heart failure. Paradoxically, these beneficial effects may be due to the buildup of bradykinin which facilitates reduced norepinephrine synthesis and release, vasodilation, and general antiproliferative effects [95].

6.3. Aldosterone Receptor Antagonists. Early on, it was assumed that ACE inhibitors would adequately limit the synthesis of aldosterone given AngII's ability to facilitate aldosterone production. However, ACE inhibition causes a transient depression in circulating aldosterone levels followed by recovery after only a few days. This turns out to be a particularly important limitation of ACE inhibition in the treatment of heart failure [96]. Elevations in circulating aldosterone have long been known to increase sodium reabsorption and potassium excretion, but increased aldosterone elevates cytokines, promotes vascular inflammation and endothelial malformation, and also myocardial fibrosis and hypertrophy. Animal model work has demonstrated a significant role for elevated aldosterone levels contributing to myocardial fibrosis [97] and left ventricular remodeling [98]. McKelvie and colleagues [99] showed that standard therapy (ACE inhibitor, $\mathrm{ARBs}$, and $\beta$-adrenergic receptor antagonist) failed to reduce circulating aldosterone levels in patients with heart failure due to left ventricular systolic dysfunction. Pitt et al. [100] treated hypertensive patients, complicated by left ventricular hypertrophy, with the selective aldosterone receptor antagonist Eplerenone, the ACE inhibitor Enalapril, or a combination of the two. Eplerenone (mean $=-14.5 \mathrm{~g}$ ) decreased left ventricular mass similar to Enalapril $(-19.7 \mathrm{~g})$, but combined treatment $(-27.2 \mathrm{~g})$ was more effective. These results suggest that an ACE inhibitor alone is not sufficient to maximize left ventricular mass reduction.

6.4. Angiotensin Receptor Blockers. Given the importance of the $\mathrm{AT}_{1}$ receptor subtype's role in contributing to the cardiovascular continuum, it seems reasonable that specific angiotensin receptor blockers could significantly reduce cardiovascular risk factors. Initial studies in canine models of left ventricular diastolic hypertrophy revealed beneficial effects due to ARB treatment [101]. The Losartan Intervention for Endpoint Reduction in Hypertension (LIFE) study found regression of left ventricular hypertrophy following long-term treatment with Losartan or Atenolol [102]. A study by Díez and colleagues [103] treated hypertensive patients with severe or nonsevere myocardial fibrosis with Losartan for 12 months. These patients demonstrated a clear improvement in left ventricular chamber stiffness as correlated with a reduction in collagen fraction volume, particularly in the severe fibrosis patients.

The Candesartan in Heart Failure Assessment of Reduction in Mortality and Morbidity (CHARM) study evaluated the contribution of ARBs in combination with ACE inhibitors, $\beta$-adrenergic antagonists, and aldosterone receptor antagonists in a large group of heart failure patients possessing left ventricular ejection fraction greater than $40 \%$. There was a trend toward fewer cardiovascular problems with Candesartan treatment than placebo [104]. However, there was an accompanying hyperkalemia and/or elevated creatinine levels in these patients.

\section{Novel Treatment Strategies}

Three novel approaches to the treatment of hypertension have focused on inhibiting the enzymes involved in the formation of AngII and AngIII, or incrementing the enzymatic pathway such that these angiotensins are rapidly degraded.

7.1. Reduction in Brain AngIII Formation via Inhibition of APA. The Llorens-Cortes research group has extended initial work completed with amastatin and bestatin by designing inhibitors with improved specificity. Reaux et al. [105] synthesized two inhibitors: one specific for APA referred to as EC33 and a second specific to APN called PC18 (m.w. $=120$ $130 \mathrm{kDa}$ for the monomer). Intracerebroventricular pretreatment with EC33 blocked the elevation in BP typically induced by the i.c.v. infusion of AngII in anesthetized SHRs. These results suggested that the AngII pressor response depended upon conversion of AngII to AngIII. Further, the i.c.v. infusion of EC33 caused a large dose-dependent decline in BP in conscious SHRs, as well as conscious DOCA-salt treated rats (a salt/volume-dependent and reninindependent model of hypertension) (Table $2[106,107]$ ). This effect could not be induced by intravenous infusion of EC33, suggesting that EC33 did not penetrate the BBB and/or was not peripherally effective. These results were interpreted to suggest that in addition to reducing conversion of AngII to AngIII, EC33 also encouraged degradation of accumulating endogenous AngII by peptidases including endopeptidases and carboxypeptidases, for example, $\mathrm{ACE}_{2}$ [108-110]. This would be expected to result in the formation of smaller AngII fragments possessing very low, or no, $\mathrm{AT}_{1}$ receptor affinity.

The conclusion that AngIII is the active ligand acting at the $\mathrm{AT}_{1}$ receptor subtype was further supported in that i.c.v.-infused PC18 in SHRs significantly increased BP [105]. This PC18-induced pressor response could be prevented by pretreatment with the specific $\mathrm{AT}_{1}$ receptor antagonist Losartan, but not by the specific $\mathrm{AT}_{2}$ receptor antagonist PD123319. Thus, these results suggest that the inhibition of APN results in the accumulation of endogenous AngIII with increased binding at the $\mathrm{AT}_{1}$ receptor subtype causing an increase in BP. Our laboratory confirmed these basic findings using metabolic-resistant analogues: D-Asp ${ }^{1}$-AngII and DArg $^{1}$-AngIII i.c.v.-infused in conscious normotensive rats in the presence or absence of EC33 or PC18 (Table 2 [91]). And finally the i.c.v. infusion of APA significantly increased blood pressure in conscious SHRs; while the i.c.v. infusion of APN decreased BP [88]. This hypertensive effect was attributed to increased endogenous levels of AngIII, and the hypotensive effect to increased AngIII degradation. Along these lines, Song and colleagues [116] reported that i.c.v. infusion of an antiserum against APA activity significantly reduced 
TABLE 2: Summary of investigations supporting a role for EC33 and PC18 (EC27) in blocking the release of vasopressin and controlling hypertension in animal models.

\begin{tabular}{|c|c|c|}
\hline Preparation & Finding & Reference \\
\hline \multirow{2}{*}{ Synthesis of EC33 } & Designed by Chauvel as a specific inhibitor of APA & \multirow{2}{*}[111]{} \\
\hline & Synthesized by Reaux and colleagues & \\
\hline \multirow{4}{*}{ i.c.v. infusion-mice } & $\begin{array}{l}\text { EC33 increased the half-life of }\left[{ }^{3} \mathrm{H}\right] \text { AngII by } 2.6 \text { fold and blocked the formation of } \\
{\left[{ }^{3} \mathrm{H}\right] \text { AngIII }}\end{array}$ & {$[108]$} \\
\hline & PC18 and EC27 increased the half-life of $\left[{ }^{3} \mathrm{H}\right]$ AngIII by 3.9 and 2.3 fold, respectively & {$[108,111]$} \\
\hline & EC33 reduced AngII-induced vasopressin release in a dose-response-dependent fashion & [111] \\
\hline & Injection of PC18 and EC27 increased vasopressin release & {$[111]$} \\
\hline Normotensive rats & Recorded from vasopressinergic neurons in the SON & \\
\hline (urethane-anesth.) & $\begin{array}{l}\text { i.c.v. infusion of AngII and AngIII significantly increased firing rate. i.c.v. infusion of } \\
\text { EC33 abruptly stopped firing rate for } 4-6 \text { min. i.c.v. infusion of AngII followed by EC33 } \\
\text { prevented the increase in firing rate to AngII }\end{array}$ & {$[112]$} \\
\hline i.c.v. infusion-SHRs & EC33 blocked AngII-induced pressor responses & {$[105,113]$} \\
\hline $\begin{array}{l}\text { i.c.v. infusion- } \\
\text { normotensive } \\
\text { rats }\end{array}$ & $\begin{array}{l}\text { EC33 blocked the pressor response induced by AngII and D-Asp }{ }^{1} \text { AngII but had no effect } \\
\text { on the pressor responses induced by AngIII or D-Arg }{ }^{1} \text { AngIII. PC18 extended the } \\
\text { duration of the D-Asp }{ }^{1} \text { AngII-induced pressor response } 2.5 \text { fold, and the duration of the } \\
\text { D-Arg }{ }^{1} \text { AngIII-induced pressor response by } 10 \text { to } 15 \text { fold. Pretreatment with Losartan } \\
\text { blocked these pressor responses, indicating } \text { AT }_{1} \text { receptor involvement }\end{array}$ & {$[91]$} \\
\hline Synthesis of RB150 & Designed by Fournie-Zaluski & {$[107]$} \\
\hline \multirow{2}{*}{ DOCA-salt rats } & Intravenous administration of RB150 significantly reduced BP for 24 hours & {$[107]$} \\
\hline & Oral administration of RB150 significantly reduced BP for 7 hours & {$[114,115]$} \\
\hline
\end{tabular}

AngII-induced BP increases by $\sim 60 \%$. Taken together, these findings illustrate the importance of AngII conversion to AngIII in the brain but not in the periphery, regarding the mediation of BP. Thus, endogenous brain AngIII appears to exert a maintained tonic influence on centrally controlled $\mathrm{BP}$ in conscious normotensive and hypertensive animals. It is noteworthy that the inhibition of APA reduced BP to normotensive levels in hypertensive rat models.

These findings have resulted in the development of a selective orally active APA inhibitor (RB150) capable of crossing the blood-brain barrier and functioning as a antihypertensive drug (Table 2 [107]). RB150 is a pro-drug of EC33 formed from two molecules of EC33 linked by a disulfide bridge. The presence of the thiol group in the disulfide bridge prevents interaction with the zinc atom at the APA site. This bridge appears to permit $\mathrm{BBB}$ penetration, and once in the brain the disulfide bridge is removed by reductases, it yields two active EC33 molecules [117]. RB150 has been shown to function as an antihypertensive drug when given intravenously [107] or by gavage [114].

7.2. Facilitation of Angiotensin Degradation. There is considerable discrepancy in findings regarding the importance of AngIII as a mediator of peripheral BP. For example, Ahmad and Ward [118], using amastatin and bestatin, failed to confirm an important role of APA in the systemic RAS. In contrast to the finding that i.c.v.-infused EC33induced a nearly complete inhibition of APA in the rat brain [108], intravenous infusion of EC33 resulted in only limited blockade of plasma AngII conversion to AngIII [117].
There are several possible explanations for these differences comparing the brain and the periphery: (1) AngIII could be more rapidly metabolized than AngII in the periphery. However, our laboratory has determined the half-life of AngIII in the vasculature of normotensive rats to be 16.3 seconds; while the half-life of AngII was $12.5 \mathrm{sec}$ [119]; (2) the major enzyme responsible for converting AngII to AngIII in the periphery is not APA. This is unlikely given the number of studies pointing to an important role for APA in this regard (see [16-18, 20, 22, 105, 120-123] for review); (3) related to the above, alternative enzymatic pathways could be present in the peripheral circulation, for example, $\mathrm{ACE}_{2}$ may play an important role $[29,69,124]$. Clearly, there are many more enzymes involved in the metabolism of angiotensin than APA and APN [10].

As described above, the removal of the C-terminal HisLeu from AngI by ACE to form AngII, the conversion of AngII to AngIII due to the removal of Asp by APA, and the subsequent conversion of AngIII to AngIV with the removal of Arg by APN, are critical steps in determining the availability and survival rates of circulating AngII and AngIII. The hydrolysis of AngII to AngIII by APA could be the rate-limiting step in determining the level of activity of $\mathrm{AT}_{1}$ receptor activation in the periphery (see $[25,125]$ for review). In agreement with the importance of APA, recombinant human APA [126] has been shown to have value as an antihypertensive treatment in SHRs [127]. The effective dose of APA was approximately one-tenth that of the ARB Candesartan. This approach was spawned from the original observation that the SHR resembles human essential 
hypertension in that ACE inhibition, or ARB treatment, normalized BP [128, 129]. These results emphasize the importance of the RAS to the hypertension seen in this animal model. It was next confirmed that intravenous infusion of APA plus APN (purified from human placenta) lowered AngII-induced hypertension in normotensive rats [130]; while APA normalized BP in SHRs [131]. These results suggested that elevated APA could be effective in controlling high BP; while impairment of APA activity contributed to the development of hypertension. This observation supports the finding that SHRs have impaired aminopeptidase activity [132]; while renal APA activity in the SHR was found to be lower than in age-matched WKY rats [133].

The use of purified and recombinant APA is certainly worth considering for the treatment of hypertensive emergencies such as acute hypertensive crisis, preeclampsia, acute heart failure, and hypertensive encephalopathy [134, 135]. However, the notion that AngIII is the primary ligand acting at the $\mathrm{AT}_{1}$ receptor subtype in the brain's control of BP points to the importance of inhibiting APA in hypertension (Llorens-Cortes hypothesis). On the other hand, the proposal that AngII is the primary ligand acting at the $\mathrm{AT}_{1}$ receptor subtype suggests that elevations in APA should be efficacious in controlling hypertension (Mizutani hypothesis). Additional research effort will be necessary to resolve this important issue.

7.3. APN Inhibitors. Finally, there is growing interest in the development of APN inhibitors [136]. The human APN gene consists of 20 exons and maps to chromosome 15q25-26 [137]. With the use of adipocyte-derived APN, 33 polymorphisms have been identified [138]. Two of eight missense polymorphisms have been associated with arterial blood pressure, and one (Lys528Arg) has been linked to essential hypertension $[138,139]$. This Lys528rg polymorphism has been reported to inhibit APN enzymatic activity [126]. Increased urinary APN levels have been measured in renal transplant rejection patients [140] and renal cell carcinoma patients [141]. A recent study by Padia and colleagues [142] noted a defect in sodium excretion in young SHRs prior to the onset of hypertension. In this regard, young WKY rats evidenced twice the excretion rate of sodium attributed to reduced renal proximal tubule sodium reabsorption. The renal interstitial infusion of PC18 corrected this natriuresis by incrementing sodium excretion. Thus, the inhibition of AngIII metabolism by inhibiting APN corrected this proximal tubule defect in sodium excretion in SHRs. The renal interstitial infusion of AngIII produced a natriuresis in normotensive rats that was dependent on the $\mathrm{AT}_{2}$ receptor subtype [143]. The authors argue that conversion of AngII to AngIII is necessary for this natriuresis, and $\mathrm{AT}_{1}$ receptor blockade with Candesartan failed to impact these AngIIIinduced effects. The potential use of APN inhibitors for inflammatory disease and malignancies is being considered [144]; however, the testing of APN inhibitors to treat hypertensive patients is just now beginning. It should be noted that the use of APN inhibitors to control hypertensive disorders is controversial, and this area is in need of additional careful research attention.

\section{Conclusion}

Research interest in understanding the role of the RAS in the control of BP has been ongoing for over 100 years, and yet new discoveries continue to be made. Hypertension is present in approximately $16 \%$ of the adult population of the world, and $95 \%$ are categorized as essential hypertension treated with the major classes of antihypertensives including diuretics, ACE inhibitors, ARBs, $\beta$-blockers, and calcium channel blockers $[145,146]$. Despite the availaiblity of over 75 antihypertensive drugs, approximately $65 \%$ of hypertensive patients are not able to control their elevated BP [147]. And the incidence of "resistant hypertension" despite the combination of three or more drugs is around $15 \%$ of the hypertensive population [147]. Thus, we are in need for novel approaches to better treat these patients. It now appears that the importance of brain AngIII has been significantly underestimated in that the conversion of brain AngII to AngIII by APA has a major influence upon the regulation of BP and release of vasopressin. In this regard, AngIII may exert a persistent tonic influence upon BP. It is surprising that a selective APA inhibitor such as EC33 decreases BP when given centrally but not peripherally. It must be added that available results concerning RB150 are consistent in this regard. With respect to the potential use of an orally active APA inhibitor, a number of important issues remain including but not limited to: (1) the relative importance of AngIII and APA to blood pressure control comparing the brain and peripheral systems; (2) the influence of other peptidases upon the formation of angiotensin ligands; (3) the significance of the $\mathrm{AT}_{2}$ receptor subtype, and $\mathrm{Ang}(1-7)$ acting at the Mas receptor, in the control and treatment of essential hypertension.

\section{Acknowledgments}

The preparation of this paper was supported by the Edward E. and Lucille I. Laing Endowment for Alzheimer's Research and funds provided for medical and biological research by the State of Washington Initiative Measure number 171.

\section{References}

[1] R. Tigerstedt and P. G. Bergman, "Niere und Kreislauf," Scandinavian Archives of Physiology, vol. 8, pp. 223-271, 1898.

[2] H. Goldblatt, J. Lynch, R. G. Hanzal, and W. W. Summerville, "Studies on experimental hypertension: I. The production of persistent elevation of systolic blood pressure by means of renal ischemia," The Journal of Experimental Medicine, vol. 59, no. 3, pp. 347-379, 1934.

[3] E. Braun-Menendez, J. C. Fasciolo, L. F. Leloir, and J. M. Munoz, "The substance causing renal hypertension," Journal of Physiology, vol. 98, no. 3, pp. 283-298, 1940.

[4] I. H. Page and O. M. Helmer, "A crystalline pressor substance (angiotonin) resulting from the reaction between renin and renin activator," The Journal of Experimental Medicine, vol. 71, no. 1, pp. 29-42, 1940.

[5] D. F. Elliott and W. S. Peart, "Amino-acid sequence in a hypertensin,” Nature, vol. 177, no. 4507, pp. 527-528, 1956. 
[6] L. T. Skeggs, K. E. Lentz, J. R. Kahn, N. P. Shumway, and K. R. Woods, "The amino acid sequence of hypertensin. II," The Journal of Experimental Medicine, vol. 104, no. 2, pp. 193197, 1956.

[7] F. M. Bumpus, H. Schwarz, and I. H. Page, "Synthesis and pharmacology of the octapeptide angiotonin," Science, vol. 125, no. 3253, pp. 886-887, 1957.

[8] C. I. Johnston, "Biochemistry and pharmacology of the renin-angiotensin system,” Drugs, vol. 39, no. 1, pp. 21-31, 1990.

[9] V. T. Karamyan and R. C. Speth, "Enzymatic pathways of the brain renin-angiotensin system: unsolved problems and continuing challenges," Regulatory Peptides, vol. 143, no. 13, pp. 15-27, 2007.

[10] R. C. Speth and V. T. Karamyan, "The significance of brain aminopeptidases in the regulation of the actions of angiotensin peptides in the brain," Heart Failure Reviews, vol. 13, no. 3, pp. 299-309, 2008.

[11] C. M. Ferrario and W. B. Strawn, "Role of the reninangiotensin-aldosterone system and proinflammatory mediators in cardiovascular disease," American Journal of Cardiology, vol. 98, no. 1, pp. 121-128, 2006.

[12] T. Kokubu, E. Ueda, T. Joh, and K. Nishimura, "Purification and properties of angiotensin I-converting enzyme in human lung and its role on the metabolism of vasoactive peptides in pulmonary circulation," Advances in Experimental Medicine and Biology, vol. 120, pp. 467-475, 1979.

[13] T. Unger and J. Li, "The role of the renin-angiotensinaldosterone system in heart failure," JRAAS, vol. 5, no. 1, supplement, pp. S7-S10, 2004.

[14] D. H. Rich, B. J. Moon, and S. Harbeson, "Inhibition of aminopeptidases by amastatin and bestatin derivatives. Effect of inhibitor structure on slow-binding processes," Journal of Medicinal Chemistry, vol. 27, no. 4, pp. 417-422, 1984.

[15] M. Ramirez, G. Arechaga, S. Garcia, B. Sanchez, P. Lardelli, and J. M. De Gandarias, " $\mathrm{Mn}^{2+}$-activated aspartate aminopeptidase activity, subcellular localization in young and adult rat brain," Brain Research, vol. 522, no. 1, pp. 165$167,1990$.

[16] S. Wilk and D. P. Healy, "Glutamyl aminopeptidase (aminopeptidase A), the BP-1/6C3 antigen," Advances in Neuroimmunology, vol. 3, no. 3, pp. 195-207, 1993.

[17] E. N. Chauvel, C. Llorens-Cortes, P. Coric, S. Wilk, B. P. Roques, and M. C. Fournie- Zaluski, "Differential inhibition of aminopeptidase A and aminopeptidase $\mathrm{N}$ by new $\beta$-amino thiols," Journal of Medicinal Chemistry, vol. 37, no. 18, pp. 2950-2957, 1994.

[18] T. Unger, E. Badoer, D. Ganten, R. E. Lang, and R. Rettig, "Brain angiotensin: pathways and pharmacology," Circulation, vol. 77, no. 6, part 2, pp. I40-I54, 1988.

[19] J. M. Saavedra, "Brain and pituitary angiotensin," Endocrine Reviews, vol. 13, no. 2, pp. 329-380, 1992.

[20] R. C. Speth, T. E. Brown, R. D. Barnes, and J. W. Wright, "Brain angiotensinergic activity: the state of our current knowledge," Proceedings of the Western Pharmacology Society, vol. 46, pp. 11-15, 2003.

[21] T. L. Reudelhuber, "The renin-angiotensin system: peptides and enzymes beyond angiotensin II," Current Opinion in Nephrology and Hypertension, vol. 14, no. 2, pp. 155-159, 2005.

[22] I. Banegas, I. Prieto, F. Vives et al., "Brain aminopeptidases and hypertension," JRAAS, vol. 7, no. 3, pp. 129-134, 2006.

[23] International Union of Biochemistry, Nomenclature Committee, Enzyme Nomenclature 1984: Recommendations of the
Nomenclature Committee for the International Union of Biochemistry on the Nomenclature and Classification of EnzymeCatalyzed Reactions, Edited by E. C. Webb, International Union of Biochemistry Publications, Orlando, Fla, USA, 1984.

[24] S. Mizutani, K. Okano, and E. Hasegawa, "Aminopeptidase A in human placenta," Biochimica et Biophysica Acta, vol. 662, no. 1, pp. 168-170, 1981.

[25] S. Mizutani, H. Akiyama, and O. Kurauchi, "In vitro degradation of angiotensin II (A-II) by human placental subcellular fractions, pregnancy sera and purified placental aminopeptidases," Acta Endocrinologica, vol. 110, no. 1, pp. 135-139, 1985.

[26] R. Yamada, S. Mizutani, O. Kurauchi et al., "Purification and characterization of human placental aminopeptidase A," Enzyme, vol. 40, no. 4, pp. 223-230, 1988.

[27] J. W. Wright and J. W. Harding, "Important roles for angiotensin III and IV in the brain renin-angiotensin system," Brain Research Reviews, vol. 25, no. 1, pp. 96-124, 1997.

[28] C. M. Ferrario and M. C. Chappell, "Novel angiotensin peptides," Cellular and Molecular Life Sciences, vol. 61, no. 21, pp. 2720-2727, 2004.

[29] N. E. Clarke and A. J. Turner, "Angiotensin-converting enzyme 2: the first decade," International Journal of Hypertension, vol. 2012, Article ID 307315, 12 pages, 2012.

[30] G. Vauquelin, Y. Michotte, I. Smolders et al., "Cellular targets for angiotensin II fragments: pharmacological and molecular evidence," JRAAS, vol. 3, no. 4, pp. 195-204, 2002.

[31] R. Mentlein and T. Roos, "Proteases involved in the metabolism of angiotensin II, bradykinin, calcitonin gene-related peptide (CGRP), and neuropeptide Y by vascular smooth muscle cells," Peptides, vol. 17, no. 4, pp. 709-720, 1996.

[32] M. De Gasparo, K. J. Catt, T. Inagami, J. W. Wright, and T. Unger, "International union of pharmacology. XXIII. The angiotensin II receptors," Pharmacological Reviews, vol. 52, no. 3, pp. 415-472, 2000.

[33] R. M. Touyz and C. Berry, "Recent advances in angiotensin II signaling," Brazilian Journal of Medical and Biological Research, vol. 35, no. 9, pp. 1001-1015, 2002.

[34] H. Glossmann, A. Baukal, and K. J. Catt, "Angiotensin II receptors in bovine adrenal cortex. Modification of angiotensin II binding by guanyl nucleotides," The Journal of Biological Chemistry, vol. 249, no. 2, pp. 664-666, 1974.

[35] J. P. Bennett and S. H. Snyder, "Angiotensin II binding to mammalian brain membranes," The Journal of Biological Chemistry, vol. 251, no. 23, pp. 7423-7430, 1976.

[36] J. W. Harding, V. I. Cook, A. V. Miller-Wing et al., "Identification of an AII (3-8) [AIV] binding site in guinea pig hippocampus," Brain Research, vol. 583, no. 1-2, pp. 340-343, 1992.

[37] M. F. Jarvis, G. W. Gessner, and C. Q. Ly, "The angiotensin hexapeptide 3-8 fragment potently inhibits ${ }^{125} \mathrm{I}$-angiotensin II binding to non- $\mathrm{AT}_{1}$ or $-\mathrm{AT}_{2}$ recognition sites in bovine adrenal cortex," European Journal of Pharmacology, vol. 219, no. 2, pp. 319-322, 1992.

[38] G. N. Swanson, J. M. Hanesworth, M. F. Sardinia et al., "Discovery of a distinct binding site for angiotensin II (3-8), a putative angiotensin IV receptor," Regulatory Peptides, vol. 40, no. 3, pp. 409-419, 1992.

[39] S. G. Bernier, J. M. Bellemare, E. Escher, and G. Guillemette, "Characterization of $\mathrm{AT}_{4}$ receptor from bovine aortic endothelium with photosensitive analogues of angiotensin IV," Biochemistry, vol. 37, no. 12, pp. 4280-4287, 1998. 
[40] J. W. Wright, L. T. Krebs, J. W. Stobb, and J. W. Harding, "The angiotensin IV system: functional implications," Frontiers in Neuroendocrinology, vol. 16, no. 1, pp. 23-52, 1995.

[41] J. W. Wright, A. J. Bechtholt, S. L. Chambers, and J. W. Harding, "Angiotensin III and IV activation of the brain $\mathrm{AT}_{1}$ receptor subtype in cardiovascular function," Peptides, vol. 17, no. 8, pp. 1365-1371, 1996.

[42] N. Lochard, G. Thibault, D. W. Silversides, R. M. Touyz, and T. L. Reudelhuber, "Chronic production of angiotensin IV in the brain leads to hypertension that is reversible with an angiotensin $\mathrm{II} \mathrm{AT}_{1}$ receptor antagonist," Circulation Research, vol. 94, no. 11, pp. 1451-1457, 2004.

[43] R. Yang, I. Smolders, D. De Bundel et al., "Brain and peripheral angiotensin II type 1 receptors mediate renal vasoconstrictor and blood pressure responses to angiotensin IV in the rat," Journal of Hypertension, vol. 26, no. 5, pp. 9981007, 2008.

[44] R. Yang, T. Walther, F. Gembardt et al., "Renal vasoconstrictor and pressor responses to angiotensin IV in mice are $\mathrm{AT}_{1} \mathrm{a}-$ receptor mediated," Journal of Hypertension, vol. 28, no. 3, pp. 487-494, 2010.

[45] N. M. Santiago, P. S. Guimarães, R. A. Sirvente et al., "Lifetime overproduction of circulating angiotensin-(1-7) attenuates deoxycorticosterone acetate-salt hypertension-induced cardiac dysfunction and remodeling," Hypertension, vol. 55, no. 4, pp. 889-896, 2010.

[46] A. J. Ferreira, T. M. Murca, R. A. Fraga-Silva, C. H. Castro, M. K. Raizada, and R. A. S. Santos, "New cardiovascular and pulmonary therapeutic strategies based on the angiotensinconverting enzyme2/angiotensin-(1-7)/Mas receptor axis," International Journal of Hypertension, vol. 2012, Article ID 147825, 13 pages, 2012.

[47] P. P. Sayeski, M. S. Ali, D. J. Semeniuk, T. N. Doan, and K. E. Bernstein, "Angiotensin II signal transduction pathways," Regulatory Peptides, vol. 78, no. 1-3, pp. 19-29, 1998.

[48] D. T. Dinh, A. G. Frauman, C. I. Johnston, and M. E. Fabiani, "Angiotensin receptors: distribution, signalling and function," Clinical Science, vol. 100, no. 5, pp. 481-492, 2001.

[49] T. J. Murphy, R. W. Alexander, K. K. Griendling, M. S. Runge, and K. E. Bernstein, "Isolation of a cDNA encoding the vascular type-1 angiotensin II receptor," Nature, vol. 351, no. 6323, pp. 233-236, 1991.

[50] K. Sasaki, Y. Yamano, S. Bardhan et al., "Cloning and expression of a complementary DNA encoding a bovine adrenal angiotensin II type-1 receptor," Nature, vol. 351, no. 6323, pp. 230-233, 1991.

[51] K. Sandberg, H. Ji, and K. J. Catt, "Regulation of angiotensin II receptors in rat brain during dietary sodium changes," Hypertension, vol. 23, no. 1, supplement, pp. I137-I141, 1994.

[52] N. Iwai and T. Inagami, "Identification of two subtypes in the rat type I angiotensin II receptor," FEBS Letters, vol. 298, no. 2-3, pp. 257-260, 1992.

[53] S. S. Kakar, J. C. Sellers, D. C. Devor, L. C. Musgrove, and J. D. Neill, "Angiotensin II type-1 receptor subtype cDNAs: differential tissue expression and hormonal regulation," Biochemical and Biophysical Research Communications, vol. 183, no. 3, pp. 1090-1096, 1992.

[54] H. Sasamura, L. Hein, J. E. Krieger, R. E. Pratt, B. K. Kobilka, and V. J. Dzau, "Cloning, characterization, and expression of two angiotensin receptor (AT- 1) isoforms from the mouse genome," Biochemical and Biophysical Research Communications, vol. 185, no. 1, pp. 253-259, 1992.

[55] H. Konishi, S. Kuroda, Y. Inada, and Y. Fujisawa, "Novel subtype of human angiotensin II type 1 receptor: cDNA cloning and expression," Biochemical and Biophysical Research Communications, vol. 199, no. 2, pp. 467-474, 1994.

[56] D. F. Guo and T. Inagami, "The genomic organization of the rat angiotensin II receptor AT(1B)," Biochimica et Biophysica Acta, vol. 1218, no. 1, pp. 91-94, 1994.

[57] R. C. Speth, S. M. Thompson, and S. J. Johns, "Angiotensin II receptors: structural and functional considerations," in Current Concepts: Tissue Renin Angiotensin Systems as Local Regulators in Reproductive and Endocrine Organs, A. K. Mukhopadhyay and M. K. Raizada, Eds., pp. 169-192, Plenum Press, New York, NY, USA, 1995.

[58] J. M. Saavedra, "Emerging features of brain angiotensin receptors," Regulatory Peptides, vol. 85, no. 1, pp. 31-45, 1999.

[59] W. G. Thomas and F. A. O. Mendelsohn, "Angiotensin receptors: form and function and distribution," International Journal of Biochemistry and Cell Biology, vol. 35, no. 6, pp. 774-779, 2003.

[60] S. P. Bottari, V. Taylor, I. N. King, Y. Bogdal, S. Whitebread, and M. De Gasparo, "Angiotensin II $\mathrm{AT}_{2}$ receptors do not interact with guanine nucleotide binding proteins," European Journal of Pharmacology, vol. 207, no. 2, pp. 157-163, 1991.

[61] Y. Kambayashi, S. Bardhan, K. Takahashi et al., "Molecular cloning of a novel angiotensin II receptor isoform involved in phosphotyrosine phosphatase inhibition," The Journal of Biological Chemistry, vol. 268, no. 33, pp. 24543-24546, 1993.

[62] M. Mukoyama, M. Nakajima, M. Horiuchi, H. Sasamura, R. E. Pratt, and V. J. Dzau, "Expression cloning of type 2 angiotensin II receptor reveals a unique class of seventransmembrane receptors," The Journal of Biological Chemistry, vol. 268, no. 33, pp. 24539-24542, 1993.

[63] D. Young, G. Waitches, and C. Birchmeier, "Isolation and characterization of a new cellular oncogene encoding a protein with multiple potential transmembrane domains," Cell, vol. 45, no. 5, pp. 711-719, 1986.

[64] X. Xu, A. B. Quiambao, L. Roveri et al., "Degeneration of cone photoreceptors induced by expression of the Mas1 protooncogene," Experimental Neurology, vol. 163, no. 1, pp. 207-219, 2000.

[65] N. Alenina, P. Xu, B. Rentzsch, E. L. Patkin, and M. Bader, "Genetically altered animal models for Mas and angiotensin(1-7)," Experimental Physiology, vol. 93, no. 5, pp. 528-537, 2008.

[66] D. Young, K. O’Neill, T. Jessell, and M. Wigler, "Characterization of the rat mas oncogene and its high-level expression in the hippocampus and cerebral cortex of rat brain," Proceedings of the National Academy of Sciences of the United States of America, vol. 85, no. 14, pp. 5339-5342, 1988.

[67] M. Bader, "Expression of the mouse and rat mas protooncogene in the brain and peripheral tissues," FEBS Letters, vol. 357, no. 1, pp. 27-32, 1995.

[68] S. V. B. Pinheiro, A. C. Simões E Silva, W. O. Sampaio et al., "Nonpeptide AVE 0991 is an angiotensin-(1-7) receptor mas agonist in the mouse kidney," Hypertension, vol. 44, no. 4, pp. 490-496, 2004.

[69] A. J. Ferreira, T. M. Murca, R. A. Fraga-Silva, C. H. Castro, M. K. Raizada, and R. A. S. Santos, "New cardiovascular and pulmonary therapeutic strategies based on the angiotensinconverting enzyme2/angiotensin-(1-7)/Mas receptor axis," International Journal of Hypertension, vol. 2012, Article ID 147825, 13 pages, 2012.

[70] P. Xu, S. Sriramula, and E. Lazartigues, "ACE2/ANG-(17)/Mas pathway in the brain: the axis of good," American Journal of Physiology, vol. 300, no. 4, pp. R804-R817, 2011. 
[71] J. L. Grobe, A. P. Mecca, M. Lingis et al., "Prevention of angiotensin II-induced cardiac remodeling by angiotensin(1-7)," American Journal of Physiology, vol. 292, no. 2, pp. H736-H742, 2007.

[72] A. J. Ferreira, C. H. Castro, S. Guatimosim et al., "Attenuation of isoproterenol-induced cardiac fibrosis in transgenic rats harboring an angiotensin-(1-7)-producing fusion protein in the heart," Therapeutic Advances in Cardiovascular Disease, vol. 4, no. 2, pp. 83-96, 2010.

[73] N. M. Santiago, P. S. Guimarães, R. A. Sirvente et al., "Lifetime overproduction of circulating angiotensin-(1-7) attenuates deoxycorticosterone acetate-salt hypertension-induced cardiac dysfunction and remodeling," Hypertension, vol. 55, no. 4, pp. 889-896, 2010.

[74] C. Vickers, P. Hales, V. Kaushik et al., "Hydrolysis of biological peptides by human angiotensin-converting enzymerelated carboxypeptidase," The Journal of Biological Chemistry, vol. 277, no. 17, pp. 14838-14843, 2002.

[75] M. Donoghue, F. Hsieh, E. Baronas et al., "A novel angiotensin-converting enzyme-related carboxypeptidase (ACE2) converts angiotensin I to angiotensin 1-9," Circulation Research, vol. 87, no. 5, pp. E1-E9, 2000.

[76] J. A. Hernández Prada, A. J. Ferreira, M. J. Katovich et al., "Structure-based identification of small-molecule angiotensin-converting enzyme 2 activators as novel antihypertensive agents," Hypertension, vol. 51, no. 5, pp. 13121317, 2008.

[77] S. Q. Savergnini, M. Beiman, R. Q. Lautner et al., "Vascular relaxation, antihypertensive effect, and cardioprotection of a novel peptide agonist of the mas receptor," Hypertension, vol. 56, no. 1, pp. 112-120, 2010.

[78] A. J. Barret, N. D. Rawlings, and J. F. Woessner, Eds., Handbook of Proteolytic Enzymes, Academic Press, London, UK, 1998.

[79] A. L. Albiston, S. G. McDowall, D. Matsacos et al., "Evidence that the angiotensin IV (AT4) receptor is the enzyme insulin regulated aminopeptidase," The Journal of Biological Chemistry, vol. 276, no. 52, pp. 48623-48626, 2001.

[80] M. I. Phillips, "Functions of angiotensin in the central nervous system," Annual Review of Physiology, vol. 49, pp. 413435, 1987.

[81] J. W. Wright and J. W. Harding, "Regulatory role of brain angiotensins in the control of physiological and behavioral responses," Brain Research Reviews, vol. 17, no. 3, pp. 227262, 1992.

[82] D. Felix and W. Schlegel, "Angiotensin receptive neurones in the subfornical organ. Structure-activity relations," Brain Research, vol. 149, no. 1, pp. 107-116, 1978.

[83] J. W. Harding and D. Felix, "Angiotensin-sensitive neurons in the rat paraventricular nucleus: relative potencies of angiotensin II and angiotensin III," Brain Research, vol. 410, no. 1, pp. 130-134, 1987.

[84] J. W. Harding and D. Felix, "The effects of the aminopeptidase inhibitors amastatin and bestatin on angiotensinevoked neuronal activity in rat brain," Brain Research, vol. 424, no. 2, pp. 299-304, 1987.

[85] J. W. Harding, L. L. Jensen, J. M. Hanesworth, K. A. Roberts, T. A. Page, and J. W. Wright, "Release of angiotensins in paraventricular nucleus of rat in response to physiological and chemical stimuli," American Journal of Physiology, vol. 262, no. 1, pp. F17-F23, 1992.
[86] L. L. Jensen, J. W. Harding, and J. W. Wright, "Increased blood pressure induced by central application of aminopeptidase inhibitors is angiotensinergic-dependent in normotensive and hypertensive rat strains," Brain Research, vol. 490, no. 1, pp. 48-55, 1989.

[87] J. W. Wright, M. J. Sullivan, and C. R. Bredl, "Delayed cerebroventricular metabolism of ${ }^{125} \mathrm{I}$-angiotensins in the spontaneously hypertensive rat," Journal of Neurochemistry, vol. 49, no. 2, pp. 651-654, 1987.

[88] J. W. Wright, L. L. Jensen, L. L. Cushing, and J. W. Harding, "Leucine aminopeptidase M-induced reductions in blood pressure in spontaneously hypertensive rats," Hypertension, vol. 13, no. 6, pp. 910-915, 1989.

[89] J. W. Wright, S. Mizutani, C. E. Murray, H. Z. Amir, and J. W. Harding, "Aminopeptidase-induced elevations and reductions in blood pressure in the spontaneously hypertensive rat," Journal of Hypertension, vol. 8, no. 10, pp. 969-974, 1990.

[90] J. W. Wright, K. A. Roberts, V. I. Cook, C. E. Murray, M. F. Sardinia, and J. W. Harding, "Intracerebroventricularly infused $\left[{ }^{D-A r g 1}\right]$ angiotensin III, is superior to $\left[{ }^{D-A s p 1}\right]$ angiotensin II, as a pressor agent in rats," Brain Research, vol. 514, no. 1, pp. 5-10, 1990.

[91] J. W. Wright, E. Tamura-Myers, W. L. Wilson et al., "Conversion of brain angiotensin II to angiotensin III is critical for pressor response in rats," American Journal of Physiology, vol. 284, no. 3, pp. R725-R733, 2003.

[92] A. Stanton, "Potential of renin inhibition in cardiovascular disease," JRAAS, vol. 4, no. 1, pp. 6-10, 2003.

[93] L. S. Zisman, W. T. Abraham, G. E. Meixell et al., "Angiotensin II formation in the intact human heart. Predominance of the angiotensin-converting enzyme pathway," The Journal of Clinical Investigation, vol. 96, no. 3, pp. 1490-1498, 1995.

[94] I. J. Dell'Italia and A. Sabri, "Activation of the reninangiotensin system in hypertrophy and heart failure," in Heart Failure, D. L. Mann, Ed., Saunders, Philadelphia, Pa, USA, 2004.

[95] Y. H. Liu, X. P. Yang, V. G. Sharov et al., "Effects of angiotensin-converting enzyme inhibitors and angiotensin II type 1 receptor antagonists in rats with heart failure: role of kinins and angiotensin II type 2 receptors," The Journal of Clinical Investigation, vol. 99, no. 8, pp. 1926-1935, 1997.

[96] K. F. Adams Jr., "Pathophysiologic role of the reninangiotensin-aldosterone and sympathetic nervous systems in heart failure," American Journal of Health-System Pharmacy, vol. 61, supplement 2, pp. S4-S13, 2004.

[97] C. G. Brilla, R. Pick, L. B. Tan, J. S. Janicki, and K. T. Weber, "Remodeling of the rat right and left ventricles in experimental hypertension," Circulation Research, vol. 67, no. 6, pp. 1355-1364, 1990.

[98] H. N. Sabbah, P. D. Stein, T. Kono et al., "A canine model of chronic heart failure produced by multiple sequential coronary microembolizations," American Journal of Physiology, vol. 260, no. 4, pp. H1379-H1384, 1991.

[99] R. S. McKelvie, S. Yusuf, D. Pericak et al., "Comparison of candesartan, enalapril, and their combination in congestive heart failure: randomized evaluation of strategies for left ventricular dysfunction (RESOLVD) pilot study: the RESOLVD pilot study investigators," Circulation, vol. 100, no. 10, pp. 1056-1064, 1999.

[100] B. Pitt, N. Reichek, R. Willenbrock et al., "Effects of eplerenone, enalapril, and eplerenone/enalapril in patients 
with essential hypertension and left ventricular hypertrophy: the 4E-Left Ventricular Hypertrophy Study," Circulation, vol. 108, no. 15, pp. 1831-1838, 2003.

[101] W. Hayashida, J. Donckier, H. Van Mechelen, A. A. Charlier, and H. Pouleur, "Diastolic properties in canine hypertensive left ventricular hypertrophy: effects of angiotensin converting enzyme inhibition and angiotensin II type-1 receptor blockade," Cardiovascular Research, vol. 33, no. 1, pp. 54-62, 1997.

[102] K. Wachtell, J. N. Bella, J. Rokkedal et al., "Change in diastolic left ventricular filling after one year of antihypertensive treatment: the losartan intervention for endpoint reduction in hypertension (LIFE) study," Circulation, vol. 105, no. 9, pp. 1071-1076, 2002.

[103] J. Díez, R. Querejeta, B. López, A. González, M. Larman, and J. L. Martínez Ubago, "Losartan-dependent regression of myocardial fibrosis is associated with reduction of left ventricular chamber stiffness in hypertensive patients," Circulation, vol. 105, no. 21, pp. 2512-2517, 2002.

[104] S. Yusuf, M. A. Pfeffer, K. Swedberg et al., "Effects of candesartan in patients with chronic heart failure and preserved left-ventricular ejection fraction: the CHARM-preserved trial," The Lancet, vol. 362, no. 9386, pp. 777-781, 2003.

[105] A. Reaux, M. C. Fournie-Zaluski, C. David et al., "Aminopeptidase A inhibitors as potential central antihypertensive agents," Proceedings of the National Academy of Sciences of the United States of America, vol. 96, no. 23, pp. 13415-13420, 1999.

[106] J. J. Morton, J. Casals-Stenzel, and A. F. Lever, "Inhibitors of the renin-angiotensin system in experimental hypertension, with a note on the measurement of angiotensin I, II and III during infusion of converting-enzyme inhibitor," British Journal of Clinical Pharmacology, vol. 7, supplement 2, pp. 233S-241S, 1979.

[107] M. C. Fournie-Zaluski, C. Fassot, B. Valentin et al., "Brain renin-angiotensin system blockade by systemically active aminopeptidase A inhibitors: a potential treatment of salt-dependent hypertension," Proceedings of the National Academy of Sciences of the United States of America, vol. 101, no. 20, pp. 7775-7780, 2004.

[108] S. Zini, M. C. Fournie-Zaluski, E. Chauvel, B. P. Roques, P. Corvol, and C. Llorens-Cortes, "Identification of metabolic pathways of brain angiotensin II and III using specific aminopeptidase inhibitors: predominant role of angiotensin III in the control of vasopressin release," Proceedings of the National Academy of Sciences of the United States of America, vol. 93, no. 21, pp. 11968-11973, 1996.

[109] C. M. Ferrario, "Angiotensin-converting enzyme 2 and angiotensin-(1-7): an evolving story in cardiovascular regulation," Hypertension, vol. 47, no. 3, pp. 515-521, 2006.

[110] R. J. Kokje, W. L. Wilson, T. E. Brown, V. T. Karamyan, J. W. Wright, and R. C. Speth, "Central pressor actions of aminopeptidase-resistant angiotensin II analogs: challenging the angiotensin III hypothesis," Hypertension, vol. 49, no. 6, pp. 1328-1335, 2007.

[111] A. Reaux, M. C. Fournie-Zaluski, and C. Llorens-Cortes, "Angiotensin III: a central regulator of vasopressin release and blood pressure," Trends in Endocrinology and Metabolism, vol. 12, no. 4, pp. 157-162, 2001.

[112] S. Zini, Y. Demassey, M. C. Fournié-Zaluski et al., "Inhibition of vasopressinergic neurons by central injection of a specific aminopeptidase A inhibitor," NeuroReport, vol. 9, no. 5, pp. 825-828, 1998.
[113] A. Réaux, N. De Mota, S. Zini et al., "PC18, a specific aminopeptidase $\mathrm{N}$ inhibitor, induces vasopressin release by increasing the half-life of brain Angiotensin III," Neuroendocrinology, vol. 69, no. 5, pp. 370-376, 1999.

[114] L. Bodineau, A. Frugière, Y. Marc et al., "Orally active aminopeptidase A inhibitors reduce blood pressure: a new strategy for treating hypertension," Hypertension, vol. 51, no. 5, pp. 1318-1325, 2008.

[115] L. Bodineau, A. Frugière, Y. Marc, C. Claperon, and C. Llorens-Cortes, "Aminopeptidase A inhibitors as centrally acting antihypertensive agents," Heart Failure Reviews, vol. 13, no. 3, pp. 311-319, 2008.

[116] L. Song, S. Wilk, and D. P. Healy, "Aminopeptidase A antiserum inhibits intracerebroventricular angiotensin IIinduced dipsogenic and pressor responses," Brain Research, vol. 744, no. 1, pp. 1-6, 1997.

[117] Y. Marc and C. Llorens-Cortes, "The role of the brain reninangiotensin system in hypertension: implications for new treatment," Progress in Neurobiology, vol. 95, no. 2, pp. 89103, 2011.

[118] S. Ahmad and P. E. Ward, "Role of aminopeptidase activity in the regulation of the pressor activity of circulating angiotensins," Journal of Pharmacology and Experimental Therapeutics, vol. 252, no. 2, pp. 643-650, 1990.

[119] J. W. Harding, M. S. Yoshida, and R. P. Dilts, "Cerebroventricular and intravascular metabolism of ${ }^{125} \mathrm{I}$-angiotensins in rat," Journal of Neurochemistry, vol. 46, no. 4, pp. 1292-1297, 1986.

[120] D. H. Rich, B. J. Moon, and S. Harbeson, "Inhibition of aminopeptidases by amastatin and bestatin derivatives. Effect of inhibitor structure on slow-binding processes," Journal of Medicinal Chemistry, vol. 27, no. 4, pp. 417-422, 1984.

[121] M. Ramirez, G. Arechaga, S. Garcia, B. Sanchez, P. Lardelli, and J. M. De Gandarias, " $\mathrm{Mn}^{2+}$-activated aspartate aminopeptidase activity, subcellular localization in young and adult rat brain," Brain Research, vol. 522, no. 1, pp. 165167, 1990.

[122] R. Ardaillou, "Active fragments of angiotensin II: enzymatic pathways of synthesis and biological effects," Current Opinion in Nephrology and Hypertension, vol. 6, no. 1, pp. 28-34, 1997.

[123] M. Ramírez, I. Prieto, F. Alba, F. Vives, I. Banegas, and M. de Gasparo, "Role of central and peripheral aminopeptidase activities in the control of blood pressure: a working hypothesis," Heart Failure Reviews, vol. 13, no. 3, pp. 339353, 2008.

[124] S. Bernardi, W. C. Burns, B. Toffoli et al., "Angiotensin converting enzyme 2 regulates renal atrial natriuretic peptide through angiotensin-(1-7)," Clinical Science, vol. 123, no. 1, pp. 29-37, 2012.

[125] J. W. Wright and J. W. Harding, "Brain renin-angiotensin-A new look at an old system," Progress in Neurobiology, vol. 95, no. 1, pp. 49-67, 2011.

[126] Y. Goto, A. Hattori, Y. Ishii, and M. Tsujimoto, "Reduced activity of the hypertension-associated Lys528Arg mutant of human adipocyte-derived leucine aminopeptidase (ALAP)/ER-aminopeptidase-1," FEBS Letters, vol. 580, no. 7, pp. 1833-1838, 2006.

[127] M. Ishii, A. Hattori, Y. Numaguchi et al., "The effect of recombinant aminopeptidase A on hypertension in spontaneously hypertensive rats: its effect in comparison with candesartan," Hormone and Metabolic Research, vol. 40, no. 12, pp. 887-891, 2008. 
[128] D. P. Healy and L. Song, "Kidney aminopeptidase A and hypertension, part I: spontaneously hypertensive rats," Hypertension, vol. 33, no. 2, pp. 740-745, 1999.

[129] W. Raasch, O. Jöhren, S. Schwartz, A. Gieselberg, and P. Dominiak, "Combined blockade of $\mathrm{AT}_{1}$-receptors and $\mathrm{ACE}$ synergistically potentiates antihypertensive effects in SHR," Journal of Hypertension, vol. 22, no. 3, pp. 611-618, 2004.

[130] S. Mizutani, K. Okano, and E. Hasegawa, "Human placental leucine aminopeptidase (P-LAP) as a hypotensive agent," Experientia, vol. 38, no. 7, pp. 821-822, 1982.

[131] S. Mizutani, M. Furuhashi, H. Imaizumi, Y. Ito, O. Kurauchi, and Y. Tomoda, "Effects of human placental aminopeptidases in spontaneously hypertensive rats," Medicinal Science Research, vol. 15, no. 1, pp. 1203-1204, 1987.

[132] J. W. Wright, M. J. Sullivan, and J. W. Harding, "Dysfunction of central angiotensinergic aminopeptidase activity in spontaneously hypertensive rats," Neuroscience Letters, vol. 61, no. 3, pp. 351-356, 1985.

[133] Y. Nakashima, Y. Ohno, A. Itakura et al., "Possible involvement of aminopeptidase A in hypertension in spontaneously hypertensive rats (SHRs) and change of refractoriness in response to angiotensin II in pregnant SHRs," Journal of Hypertension, vol. 20, no. 11, pp. 2233-2238, 2002.

[134] S. Mizutani, J. Wright, and H. Kobayashi, "A new approach regarding the treatment of preeclampsia and preterm labor," Life Sciences, vol. 88, no. 1-2, pp. 17-23, 2011.

[135] H. Kobayashi, S. Mizutani, and J. W. Wright, "Placental leucine aminopeptidase- and aminopeptidase A-deficient mice offer insight concerning the mechanisms underlying preterm labor and preeclampsia," Journal of Biomedicine and Biotechnology, vol. 2011, Article ID 286947, 12 pages, 2011.

[136] R. S. Danziger, "Aminopeptidase N in arterial hypertension," Heart Failure Reviews, vol. 13, no. 3, pp. 293-298, 2008.

[137] C. Lerche, L. K. Vogel, L. H. Shapiro, O. Norén, and H. Sjöström, "Human aminopeptidase $\mathrm{N}$ is encoded by 20 exons," Mammalian Genome, vol. 7, no. 9, pp. 712-713, 1996.

[138] N. Yamamoto, J. Nakayama, K. Yamakawa-Kobayashi, H. Hamaguchi, R. Miyazaki, and T. Arinami, "Identification of 33 polymorphisms in the adipocyte-derived leucine aminopeptidase (ALAP) gene and possible association with hypertension," Human Mutation, vol. 19, no. 3, pp. 251-257, 2002.

[139] J. S. Williams, A. Raji, G. H. Williams, and P. R. Conlin, "Nonmodulating hypertension is associated with insulin resistance and the Lys528Arg variant human adipocytederived leucine aminopeptidase," Hypertension, vol. 48, no. 4, article e33, 2006.

[140] K. Sri Krishna, M. G. Kirubakaran, A. P. Pandey, and A. S. Kanagasabapathy, "Urinary $\mathrm{N}$-acetyl- $\beta$-d-glucosaminidase and aminopeptidase $\mathrm{N}$ in the diagnosis of graft rejection after live donor renal transplantation," Clinica Chimica Acta, vol. 150, no. 2, pp. 69-85, 1985.

[141] Y. Kitamura, M. Watanabe, S. Komatsubara, and Y. Sakata, "Urinary excretion of glycine.prolile dipeptidile aminopeptidase, N-acetyl-beta-D-glucosaminidase, alanine aminopeptidase and low molecular protein in patients with renal cell carcinoma," Acta Urologica Japonica, vol. 36, no. 5, pp. 535$539,1990$.

[142] S. H. Padia, N. L. Howell, B. A. Kemp, M. C. Fournie-Zaluski, B. P. Roques, and R. M. Carey, "Intrarenal aminopeptidase N inhibition restores defective angiontesin II type 2-mediated natriuresis in spontaneously hypertensive rats," Hypertension, vol. 55, no. 2, pp. 474-480, 2010.

[143] S. H. Padia, B. A. Kemp, N. L. Howell, J. J. Gildea, S. R. Keller, and R. M. Carey, "Intrarenal angiotensin III infusion induces natriuresis and angiotensin type 2 receptor translocation in Wistar-Kyoto but not in spontaneously hypertensive rats," Hypertension, vol. 53, no. 2, pp. 338-343, 2009.

[144] B. Bauvois and D. Dauzonne, "Aminopeptidase-N/CD13 (EC 3.4.11.2) inhibitors: chemistry, biological evaluations, and therapeutic prospects," Medicinal Research Reviews, vol. 26, no. 1, pp. 88-130, 2006.

[145] R. Düsing, "Optimizing blood pressure control through the use of fixed combinations," Vascular Health and Risk Management, vol. 6, pp. 321-325, 2010.

[146] P. M. Kearney, M. Whelton, K. Reynolds, P. Muntner, P. K. Whelton, and J. He, "Global burden of hypertension: analysis of worldwide data," The Lancet, vol. 365, no. 9455, pp. 217223, 2005.

[147] K. Wolf-Maier, R. S. Cooper, H. Kramer et al., "Hypertension treatment and control in five European countries, Canada, and the United States," Hypertension, vol. 43, no. 1, pp. 1017,2004 


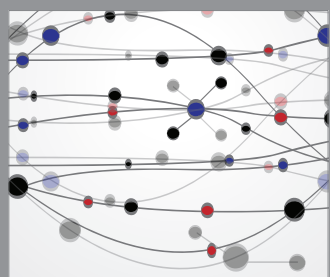

The Scientific World Journal
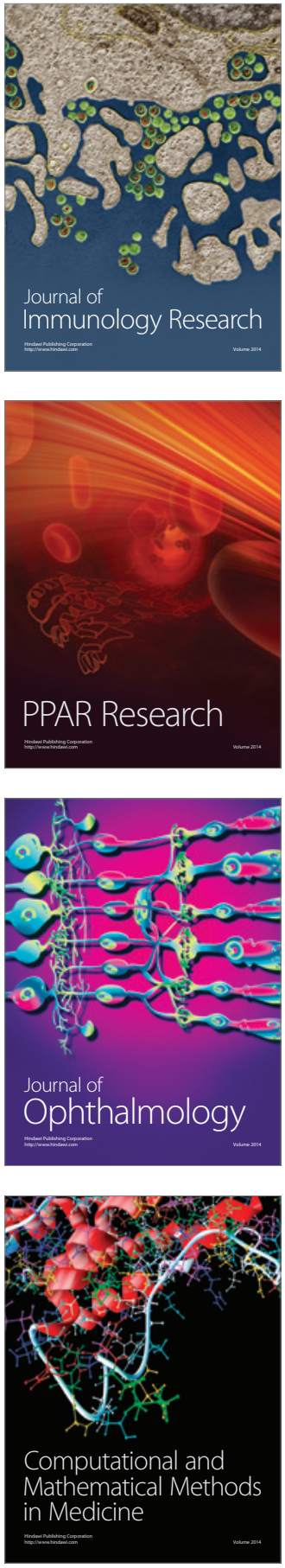

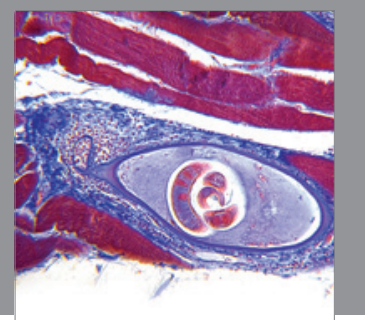

Gastroenterology

Research and Practice
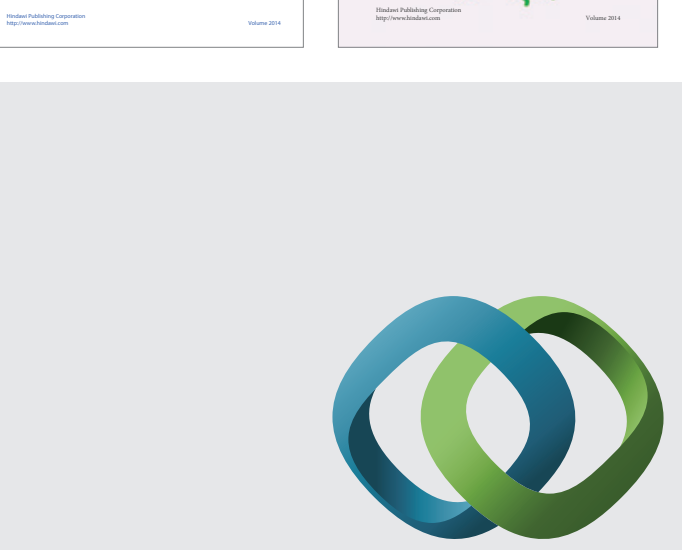

\section{Hindawi}

Submit your manuscripts at

http://www.hindawi.com
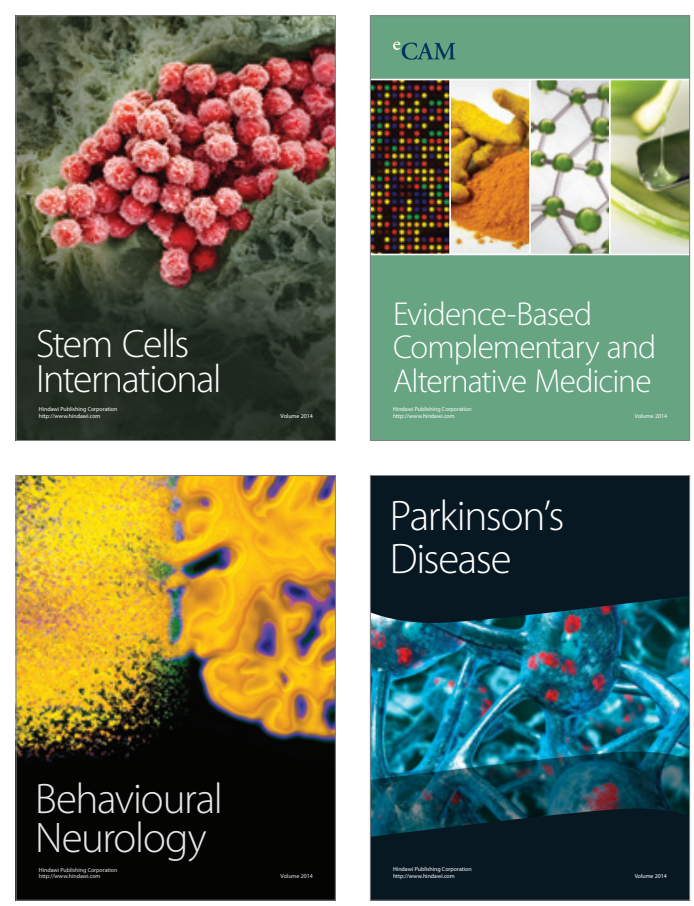

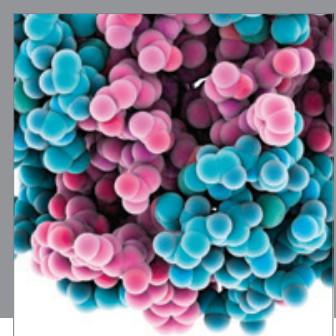

Journal of
Diabetes Research

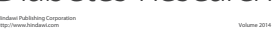

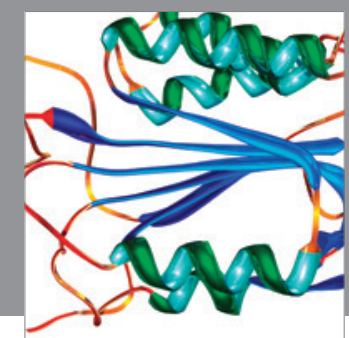

Disease Markers
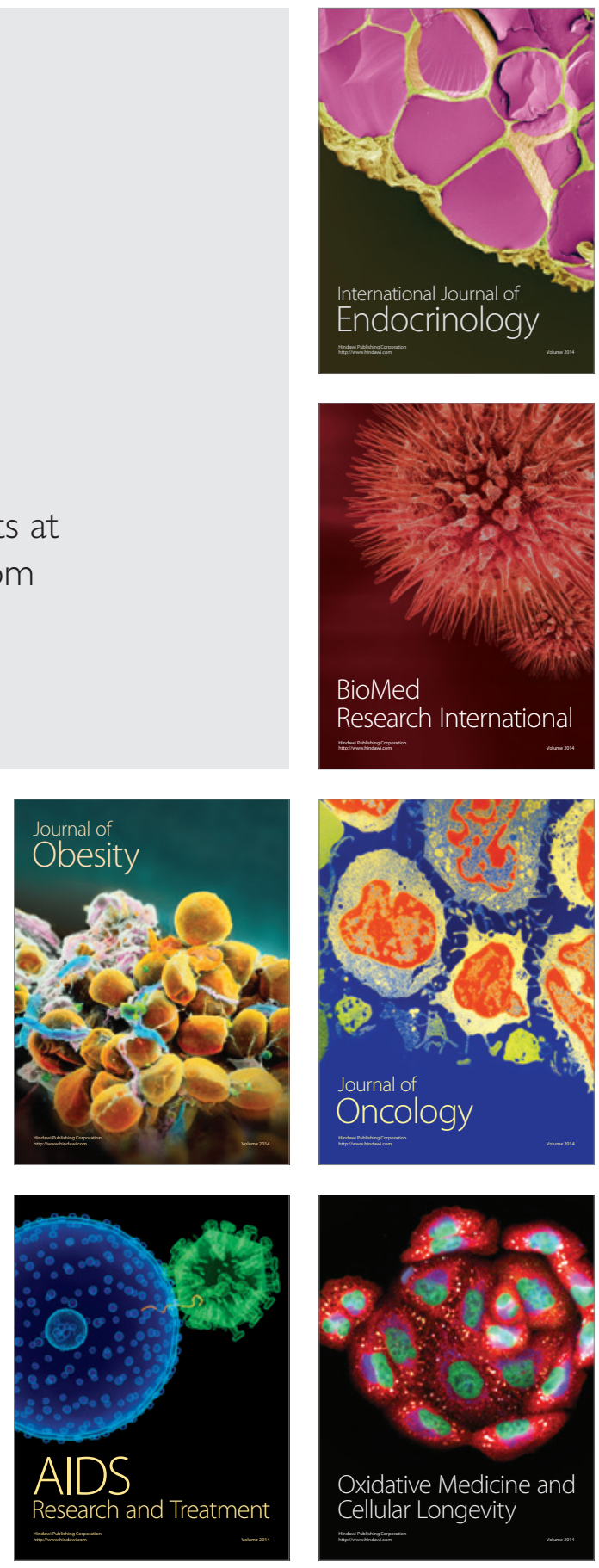